\title{
Accumulation and suppressive function of regulatory $T$ cells in malignant ascites: Reducing their suppressive function using arsenic trioxide in vitro
}

\author{
ZILONG HU ${ }^{1}$, SHIDONG HU ${ }^{1}$, YOUJUN WU ${ }^{1}$, SONGYAN LI ${ }^{1}$, CHANGZHENG HE $^{1}$, \\ XIAOWEI XING ${ }^{1}$, YUFENG WANG ${ }^{2}$ and XIAOHUI DU ${ }^{1}$ \\ Departments of ${ }^{1}$ General Surgery and ${ }^{2}$ Patient Admission Management, \\ Chinese People's Liberation Army General Hospital, Beijing 100853, P.R. China
}

Received September 25, 2017; Accepted January 15, 2018

DOI: $10.3892 / \mathrm{ol} .2018 .7974$

\begin{abstract}
Although adoptive cell therapy (ACT) has demonstrated effective and remarkable clinical responses in several studies, this approach does not lead to objective clinical responses in all cases. The function of ACT is often compromised by various tumor escape mechanisms, including the accumulation of immunoregulatory cells. As a result of peritoneal metastasis in the terminal stage, malignant ascites fluid lacks effectiveness and is a poor prognostic factor for gastric cancer. The present study assessed T-cell subsets in lymphocytes derived from malignant ascites, and investigated the effects of arsenic trioxide $\left(\mathrm{As}_{2} \mathrm{O}_{3}\right)$ on regulatory $\mathrm{T}$ cells (Tregs) and ascites-derived tumor-infiltrating lymphocytes (TILs) in vitro. In this study, lymphocytes were separated from malignant ascites and T-cell subsets were detected via flow cytometry. Forkhead box P3 (FoxP3) expression was assessed by immunohistochemistry and reverse transcription-quantitative polymerase chain reaction. In addition, cytokines, including interleukin-10 (IL-10), transforming growth factor- $\beta$ (TGF- $\beta$ ), and interferon- $\gamma$ (IFN- $\gamma$ ), were measured by enzyme-linked immunosorbent assay (ELISA). Abundant Tregs were observed in ascites lymphocytes, which and exhibited a significantly increased frequency compared with that in the peripheral blood of patients. Furthermore, $\mathrm{As}_{2} \mathrm{O}_{3}$ treatment significantly reduced Treg numbers and Foxp3 mRNA levels in vitro $(\mathrm{P}<0.05)$. IFN- $\gamma$ levels in the supernatant of ascites-derived TILs were increased by $\mathrm{As}_{2} \mathrm{O}_{3}$, whereas IL-10 and TGF- $\beta$ levels were significantly reduced $(\mathrm{P}<0.05) . \mathrm{As}_{2} \mathrm{O}_{3}$ may induce selective depletion and inhibit immunosuppressive
\end{abstract}

Correspondence to: Professor Xiaohui Du, Department of General Surgery, Chinese People's Liberation Army General Hospital, 28 Fuxing Road, Beijing 100853, P.R. China

E-mail: duxiaohui301@sina.com

Key words: immunotherapy, regulatory $\mathrm{T}$ cells, arsenic trioxide, malignant ascites function of Tregs, and may enhance the cytotoxic activity of ascites-derived TILs.

\section{Introduction}

Immunotherapy has been widely applied in a clinical setting and has achieved success in treating several malignant tumors. Nevertheless, the effectiveness of adoptive cell therapy (ACT) is often compromised by various tumor escape mechanisms, including the accumulation of immunoregulatory cells. Regulatory $\mathrm{T}$ cells (Tregs) comprise a highly immunosuppressive subset of $\mathrm{CD}^{+} \mathrm{T}$ cells, which was first identified by Sakaguchi et al (1) in 1995. This subpopulation plays a critical role in tumor immunological escape; Tregs are responsible for a weakened immune response $(2,3)$. An increase in Tregs has been demonstrated in a variety of different cancers including melanoma, ovarian, glioblastoma, breast, colorectal, and lung cancers $(4,5)$. Previous studies have shown that, in addition to those found in the tumor site and peripheral blood, Tregs isolated from malignant ascites were equally able to exhibit potent suppressive effects on tumor-antigen specific immunity (6). Tregs are thought to contribute to tumor progression because of their recruitment in the tumor microenvironment. Therefore, reducing the number of Tregs and blockading their immune inhibitory role has become a critical issue for improving cancer immunotherapy.

Arsenic trioxide $\left(\mathrm{As}_{2} \mathrm{O}_{3}\right)$ has been used as the standard treatment for acute lymphoblastic leukemia in adults. In many solid tumors, $\mathrm{As}_{2} \mathrm{O}_{3}$ shows antitumor effects by inhibiting proliferation and inducing apoptosis of tumor cells (7-9). $\mathrm{As}_{2} \mathrm{O}_{3}$ can reportedly modulate the immune response by promoting apoptosis of $\mathrm{CD}^{+} \mathrm{T}$ lymphocytes. It was demonstrated that low doses of $\mathrm{As}_{2} \mathrm{O}_{3}$ can inhibit tumor growth by reducing the number of Tregs through oxidative and nitrosative bursts. These researchers suggested that $\mathrm{As}_{2} \mathrm{O}_{3}$ is useful in enhancing the antitumor activity of adoptive immunotherapy $(10,11)$. Malignant ascites, which results from peritoneal metastasis in advanced gastric cancer, has an extremely poor prognosis and lacks an effective treatment. High Treg levels have been found in malignant ascites and are seen play a key role in tumor progression and metastasis (12). In the present study, 
we assessed the proportion of T-cell subsets in ascites-derived tumor-infiltrating lymphocytes (TILs) and peripheral blood mononuclear cells (PBMCs) obtained from gastric cancer patients. The effects of $\mathrm{As}_{2} \mathrm{O}_{3}$ on the suppressive function of Tregs and the cytotoxicity of ascites-derived TILs in vitro were also examined.

\section{Materials and methods}

Reagents and cell lines. $\mathrm{As}_{2} \mathrm{O}_{3}$ (Sigma, St. Louis, MO, USA) was stored at $4^{\circ} \mathrm{C}$ after purchase. Human gastric cancer BGC823 cells were obtained from the Institute of General Surgery, Chinese PLA General Hospital (Beijing, China). These cells were cultured in RPMI-1640 medium (Gibbon, Grand Island, NY, USA), supplemented with $10 \%$ heat-inactivated fetal bovine serum (FBS), $4 \mathrm{mM}$ glutamine, $50 \mathrm{U} / \mathrm{ml}$ penicillin, and $50 \mathrm{mg} / \mathrm{ml}$ streptomycin, at $37^{\circ} \mathrm{C}$ in a $5 \% \mathrm{CO}_{2}$ incubator (Thermo Scientific, Waltham, MA, USA).

Preparation of PBMCs. Density gradient centrifugation and lymphocyte separation medium (Xinminglitai, Beijing, China) were used to prepare a mononuclear cell suspension. A 20-ml volume of peripheral blood was obtained from eight gastric cancer patients and eight healthy donors. Samples were collected in a 50-ml centrifuge tube, and the serum was removed after centrifuging at 3,000 rpm/min for $30 \mathrm{~min}$. A 50-ml centrifuge tube was filled with normal saline (NS), and another 50-ml centrifuge tube containing 20-ml lymphocyte separation medium was also prepared. The blood was mixed with the NS and added to the surface of the lymphocyte separation medium. After the supernatant was removed, mononuclear cells were collected from the corresponding layer and placed into another $50-\mathrm{ml}$ centrifuge tube. The serum was removed after centrifugation, and NS was added to the tube. The PBMCs were obtained after centrifuging at $1,700 \mathrm{rpm} / \mathrm{min}$ for $10 \mathrm{~min}$ and removal of the serum.

Preparation of ascites-derived TILs. Diagnosis of gastric cancer was determined by tumor biopsy; all patients consented to provide ascites fluid through a correlative science protocol approved by the institutional review board. A volume of 500-800 ml ascites fluid was obtained aseptically from each patient with malignant ascites. The supernatant was removed after centrifugation at $1,500 \mathrm{rpm} / \mathrm{min}$ for $20 \mathrm{~min}$, and the red blood cells were lysed in a lysis buffer. Adherent cells, including fibrocytes and macrophages, were removed and resuspended in a medium supplemented with inactivated fetal bovine serum (Gibco Inc., Grand Island, NY, USA). To this, $20 \mathrm{ml}$ human lymphocyte separation medium (Chinese Academy of Medical Sciences, Beijing, China) was added. After centrifugation at $2,000 \mathrm{rpm} / \mathrm{min}$ for $20 \mathrm{~min}$, the nonadherent floating cells were collected to obtain the ascites lymphocytes (ALs): $4 \times 10^{5}$ cells were acquired for flow cytometric detection. Next, the ALs were cultured in 25-mm T-type flasks in RPMI-1640 medium, supplemented with $20 \%$ inactivated $\mathrm{FBS}$, at $37^{\circ} \mathrm{C}$ in $5 \% \mathrm{ChO}_{2}$. After $24 \mathrm{~h}, 2 \mu \mathrm{g} / \mathrm{ml}$ anti-CD3 McAb (BD Biosciences, NJ, USA) and 1,000 U/ml recombinant human interleukin-2 (IL-2; R\&D Systems, Inc., Minneapolis, MN, USA) were added. On day 5 , the medium was replaced with Cellix 602 serum-free medium (Xinminglitai). The media and recombinant human IL-2 were supplemented, if necessary. On day 14, TILs were harvested. In our in vitro studies, $2 \times 10^{7} \mathrm{TILs}$ were treated with different doses of $\mathrm{As}_{2} \mathrm{O}_{3}(1,5$ or $10 \mu \mathrm{M})$ for $48 \mathrm{~h}$. The percentage of $\mathrm{CD}^{+} \mathrm{T}$ cells, $\mathrm{CD}^{+} \mathrm{T}$ cells, and $\mathrm{CD} 4^{+} / \mathrm{CD} 25^{+} / \mathrm{CD} 127^{\text {low }}$ Tregs were detected by flow cytometry. Forkhead box P3 (FoxP3) expression, interferon- $\gamma($ IFN- $\gamma$ ) levels in the supernatant, and cytotoxic activity of TILs were also evaluated and analyzed.

Reverse transcription-quantitative polymerase chain reaction (RT-qPCR) detection of Foxp3. Total RNA was extracted from target cells using TRIzol reagent (Life Technologies, Rockville, MD, USA), according to the manufacturer's directions. The amount of total RNA was determined by spectrophotometrically measuring the absorbance at $260 \mathrm{~nm}$. Complementary DNA (cDNA) was synthesized from $1 \mu \mathrm{g}$ of total RNA using the PrimeScript 1st Strand cDNA Synthesis kit (Takara, Beijing, China). The reactions were run with SYBR-Green on a Corbett Rotor-Gene 3000 (Corbett Research, Concorde, Australia) real-time thermal cycler. Data were expressed by the comparative threshold cycle method and normalized to the $\beta$-actin. The sequences of primers were synthesized as follows: Human $\beta$-actin primer sequences $\mathrm{H}-\beta$-actin-F, 5'TAG TTGCGTTACACCCTTTCTTG-3' and H- $\beta$-actin-R, 5'-TCA CCTTCACCGTTCCAGTTT-3'; and human Foxp3 primer sequences HFoxp3-F, 5'-AGGAAAGGAGGATGGACGAA-3' and HFoxp3-R, 5'-GCAGGCAAGACAGTGGAAAC-3'.

Flow cytometry. At least $4 \times 10^{5}$ events per sample were acquired for detection by flow cytometer. Phenotypic characterization of T-cell subsets in ALs, PBMCs of GC (gastric cancer patients), and PBMCs of HD (healthy donors) were performed using antibodies against CD3, CD4, CD8, CD25, CD56, and CD127 (BD Biosciences), according to the manufacturer's protocol. All samples were examined using a FACSCalibur, and the data were analyzed using FlowJo 7.6.1 software (both BD Biosciences).

Enzyme-linked immunosorbent assay (ELISA). Supernatant from the TILs were isolated from ascites-derived TILs after treated with $\mathrm{As}_{2} \mathrm{O}_{3}$ for $48 \mathrm{~h}$. The concentrations of interleukin-10 (IL-10), IFN- $\gamma$, and tumor necrosis factor- $\alpha$ (TNF- $\alpha$ ) in the supernatant were determined in triplicate using commercial ELISA kits (Sigma-Aldrich, St. Louis, MO, USA), according to the manufacturer's instructions.

Cell proliferation analysis. Ascites-derived TILs were plated in 96-well plates at $1 \times 10^{4}$ cells/well in complete medium with $20 \%$ FBS. The cells were incubated overnight at $37^{\circ} \mathrm{C}$, and the next day, $\mathrm{As}_{2} \mathrm{O}_{3}$ was added in complete growth media to a final dose of $10 \mu \mathrm{mol} / 1$. The cells were incubated with test compounds at $37^{\circ} \mathrm{C}$ in complete growth medium, and cell proliferation was evaluated using a Cell Counting kit- 8 (CCK-8; Beyotime, Shanghai, China).

Cytolytic assay. The cytotoxicity of TILs against BGC823 cells in vitro was tested by the lactate dehydrogenase (LDH) release assay (CytoTox 96 Non-Radioactive Cytotoxicity Assay; Promega Corp., Madison, WI, USA), as described previously (13). The target BGC823 cells were mixed with TILs treated with different concentrations of $\mathrm{As}_{2} \mathrm{O}_{3}$ at a ratio of 5:1 
A
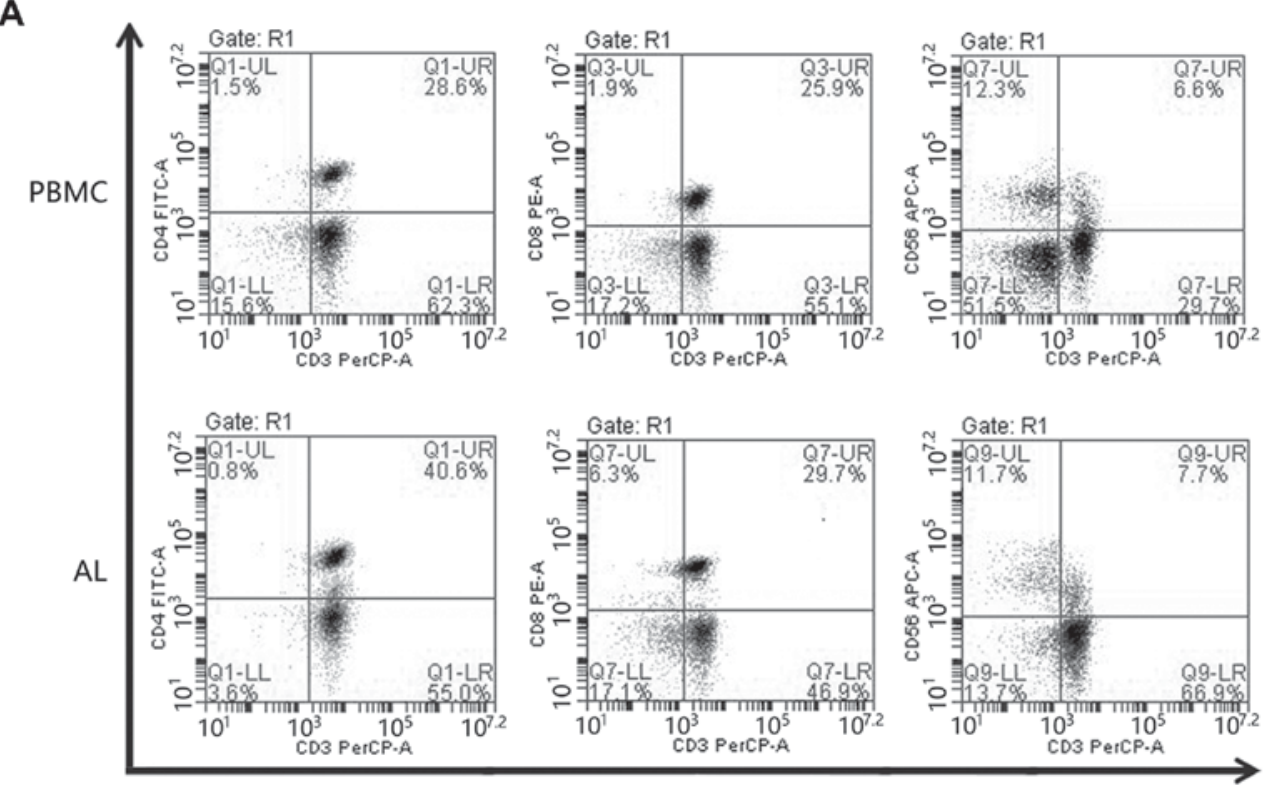

B

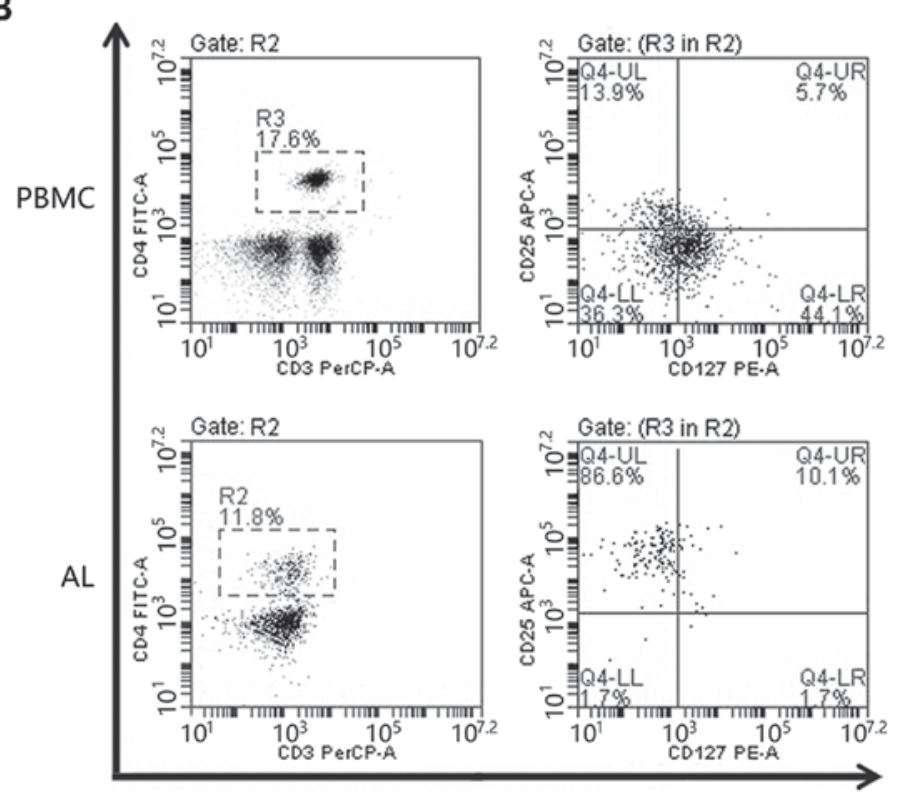

Figure 1. The phenotypic characteristics of ALs and PBMCs were all detected by flow cytometric analysis using antibodies against CD3, CD4, CD8, CD56, CD25, and CD127 (A and B). ALs, ascites lymphocytes; PBMCs, peripheral blood mononuclear cells.

or 10:1 and cultured for $24 \mathrm{~h}$. Cytotoxicity was calculated using the following formula: \%Cytotoxicity $=[\mathrm{A}($ Experimental $)$ -A (Effector Spontaneous) - A(Target Spontaneous)] x100/[A(Target maximum) - A(Target spontaneous)].

Data analysis. The descriptive data is shown as mean \pm standard deviation. Statistical analyses, including Chi-square tests, Student's $t$-tests, and Fisher's test were performed, where applicable. One-way ANOVA and post hoc test (Newman-Keuls) were applied to compare the multiple groups. For all tests, $\mathrm{P}<0.05$ was considered to indicate a statistically significant difference. Statistical Package for the Social Science (SPSS) v.23.0 (SPSS Inc., Chicago, IL, USA) and GraphPad Prism 5.0 (GraphPad Software Inc., La Jolla, CA, USA) were used for the data analysis.

\section{Results}

Phenotypic characteristics of ALs and PBMCs. To explore the proportion of T-cell subsets, the phenotypic characteristics of ALs and PBMCs derived from gastric cancer patients were detected by flow cytometry (Fig. 1). NK cells $\left(\mathrm{CD}^{-} \mathrm{CD}^{-} 6^{+}\right)$accounted for $10.5 \pm 3.6 \%$ in ALs compared to $13.1 \pm 4.1 \%$ in PBMCs of GC and $12.9 \pm 4.6 \%$ in PBMCs of HD. Furthermore, the amount of $\mathrm{CD}^{+} \mathrm{T}$ cells in PBMCs of HD, PBMCs of GC, and ALs were 26.7 $\pm 6.5,25.9 \pm 5.5$, and $28.3 \pm 7.2 \%$, respevtively. With regard to NK cells and CD8 ${ }^{+}$ $\mathrm{T}$ cells, there were no significant difference between the three groups ( $\mathrm{P}>0.05)$ (Fig. 2A and B). However, the percentage of $\mathrm{CD}^{+} \mathrm{T}$ cells was significantly increased in ALs $(41.1 \pm 7.7 \%)$ compared to PBMCs of GC $(28.7 \pm 6.2 \%)$ and PBMCs of HD 
A

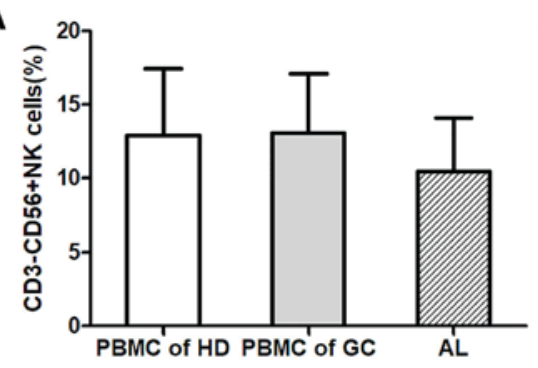

C

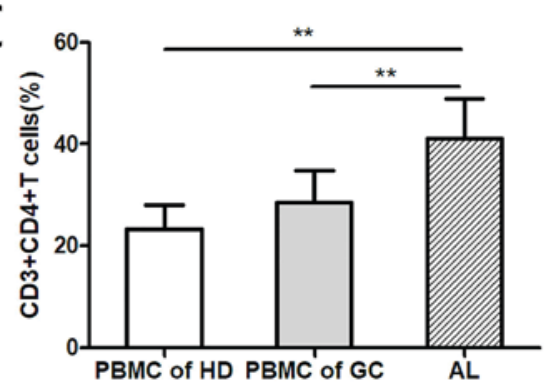

E

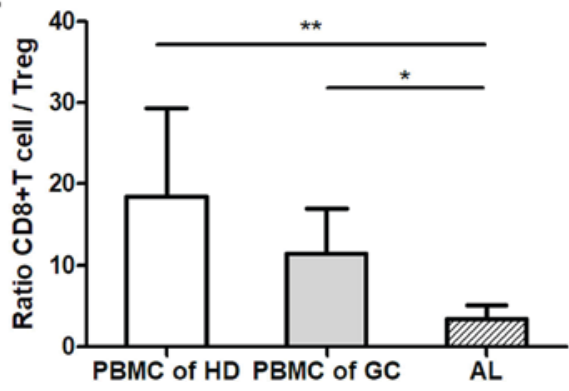

B
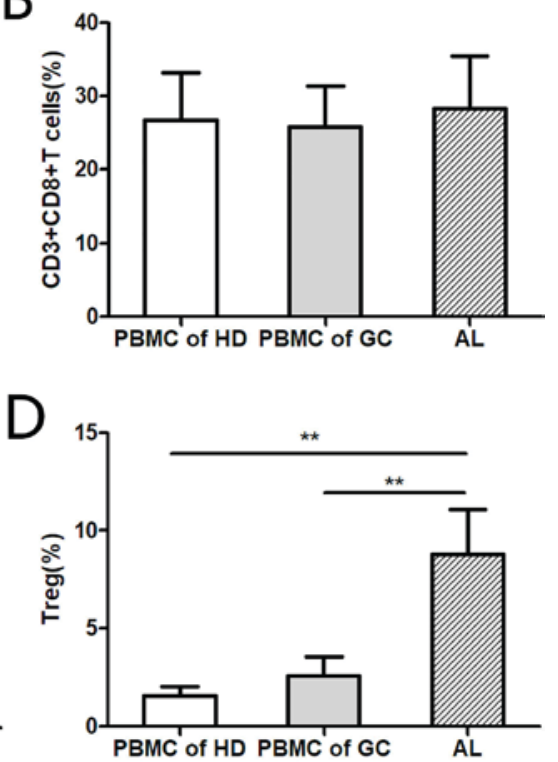

Figure 2. The percentage of T-cell subsets including helper T cells $\left(\mathrm{CD}^{+} / \mathrm{CD}^{+}\right)$, Cytotoxic $\mathrm{T}$ lymphocytes $\left(\mathrm{CD}^{+} / \mathrm{CD}^{+}\right)$, $\mathrm{NK}^{-e l l s}\left(\mathrm{CD}^{-} / \mathrm{CD}^{+} 6^{+}\right)$, and regulatory $\mathrm{T}$ cells $\left(\mathrm{CD} 4^{+} / \mathrm{CD} 25^{+} / \mathrm{CD} 127^{\text {low }}\right)$ were measured by flow cytometry. With regard to NK cells and $\mathrm{CD} 8^{+} \mathrm{T}$ cell, there were no significant differences among the groups (A and B). The results revealed a high proportion of $\mathrm{CD} 4^{+} \mathrm{T}$ cells $(\mathrm{C})$ and $\mathrm{CD}^{+} / \mathrm{CD} 25^{+} / \mathrm{CD} 127^{\text {low }} \mathrm{Tregs}(\mathrm{D})$ in ascites lymphocytes compared with PBMCs. The $\mathrm{CD}^{+} \mathrm{T}$ cell/Treg ratio was lower in TILs than in the PBMCs of patients $(\mathrm{E})\left({ }^{*} \mathrm{P}<0.05,{ }^{* *} \mathrm{P}<0.01\right.$ by a one-way ANOVA and post hoc test).

$(23.2 \pm 4.9)(\mathrm{P}<0.01$, Fig. $2 \mathrm{C})$. To assess the proportion of Tregs, we analyzed the $\mathrm{CD} 4^{+} / \mathrm{CD} 25^{+} / \mathrm{CD} 127^{\text {low }} \mathrm{T}$-cell subset in T cells. The result show that $\mathrm{CD} 4^{+} / \mathrm{CD} 25^{+} / \mathrm{CD} 127^{\text {low }}$ Treg made up a significantly larger proportion of T cells in ALs compared to PBMCs of GC and PBMCs of HD (P<0.01) (Fig. 2D). In addition, the $\mathrm{CD} 8^{+} \mathrm{T}$ cell/Treg ratio was lower in TILs than in the PBMCs of GC and PBMCs of HD (P<0.05) (Fig. 2E). The immunosuppressive microenvironment was reflected by this low $\mathrm{CD}^{+} \mathrm{T}$ cell/Treg ratio.

$\mathrm{As}_{2} \mathrm{O}_{3}$ treatment inhibits FoxP3 expression and cytokines secretion in ascites-derived TILs. Because expression of the transcription factor FoxP3 is critical to the immunosuppressive function of Tregs, we assessed FoxP3 mRNA expression in ascites-derived TILs by RT-qPCR. Our results revealed that both low and high doses of $\mathrm{As}_{2} \mathrm{O}_{3}$ treatment could significantly reduce FoxP3 mRNA expression, with a greater effect by doses of 5 and $10 \mu \mathrm{M}(\mathrm{P}<0.01)$ (Fig. 3A). In addition, Tregs are able to secrete immunosuppressive cytokines such as IL-10 and transforming growth factor- $\beta$ (TGF- $\beta$ ) $(14,15)$. In the present study, we found that IL-10 and TGF- $\beta$ levels in the ascites-derived TILs supernatants of the $\mathrm{As}_{2} \mathrm{O}_{3}$ treatment groups decreased when compared with the control group $(\mathrm{P}<0.01)$ (Fig. 3B and C). Meanwhile, the result of cell survival assay by CCK- 8 show that $\mathrm{As}_{2} \mathrm{O}_{3}$ treatment did not induce significant apoptosis of TILs ( $\mathrm{P}>0.05)$ (Fig. 3D). Analysis of cytokine secretion revealed a trend toward lower amounts of IL-10 and TGF- $\beta$ in $\mathrm{As}_{2} \mathrm{O}_{3}$-treated TILs than in the control group. These results suggest that $\mathrm{As}_{2} \mathrm{O}_{3}$ may functionally inhibit the immunosuppression in TILs and enhance the antitumor immune response.

$\mathrm{As}_{2} \mathrm{O}_{3}$ treatment decreases the proportion of Tregs and improved the cytotoxic activity of ascites-derived TILs in vitro. The $\mathrm{As}_{2} \mathrm{O}_{3}$ treatment groups described above were incubated at $37^{\circ} \mathrm{C}$ with $5 \% \mathrm{CO}_{2}$ for $48 \mathrm{~h}$. Phenotypic characteristics of TIL and effector cytokine (IFN- $\gamma$ ) secretions were examined by flow cytometry and ELISA. The results revealed that the percentage of $\mathrm{CD}^{+}{ }^{+} \mathrm{T}$ cells was significantly decreased in $\mathrm{As}_{2} \mathrm{O}_{3}$ treatment groups compared with the control group $(\mathrm{P}<0.05$, Fig. $4 \mathrm{~A})$. Moreover, the result showed a decreased $\mathrm{CD}^{+} / \mathrm{CD} 25^{+} / \mathrm{CD} 127^{\text {low }}$ Treg percentage in $\mathrm{As}_{2} \mathrm{O}_{3}$ treatment groups and that $5 \mu \mathrm{M} \mathrm{As}_{2} \mathrm{O}_{3}$ treatment is associated with a greater effect than the other concentrations of $\mathrm{As}_{2} \mathrm{O}_{3}$ $(\mathrm{P}<0.01)$ (Fig. 4B).

To evaluate the $\mathrm{As}_{2} \mathrm{O}_{3}$ treatment effect on cytotoxic activity of ascites-derived TILs, we detected and compared the percentage of $\mathrm{CD}^{+} \mathrm{T}$ cells among the different concentrations in $\mathrm{As}_{2} \mathrm{O}_{3}$ treatment groups. The percentage of $\mathrm{CD} 8^{+} \mathrm{T}$ cells 
A

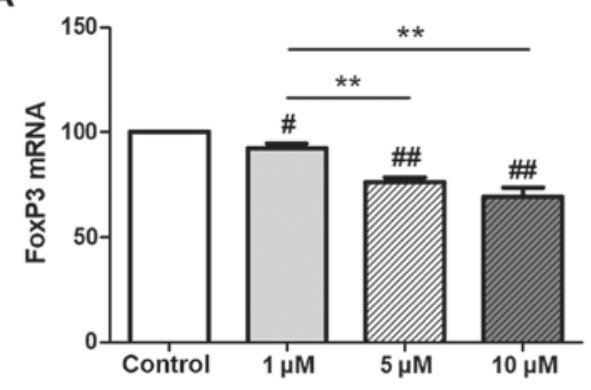

C

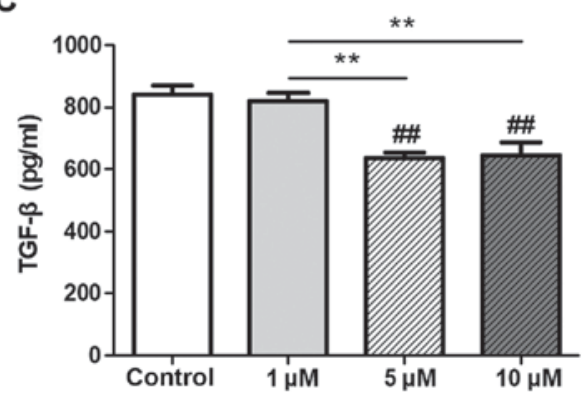

B

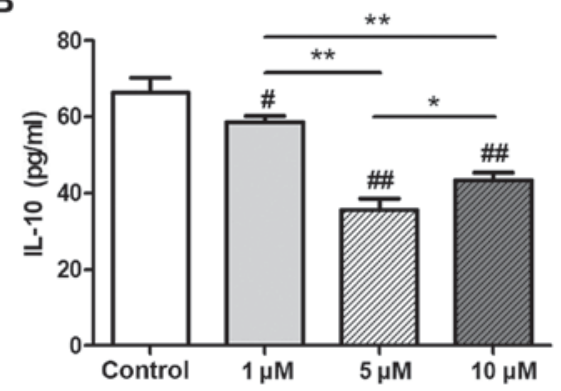

D

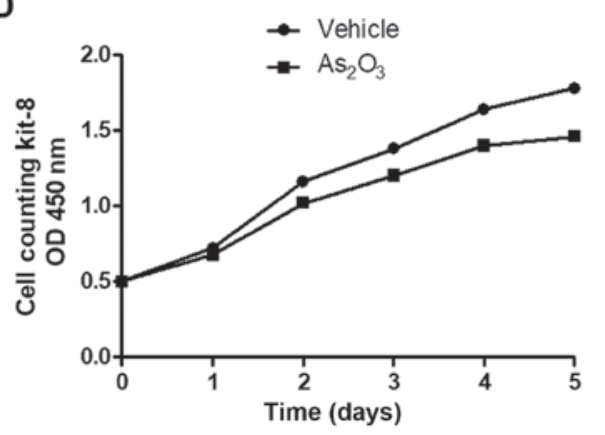

Figure 3. Effect of low-dose, medium-dose, and high-dose $\mathrm{As}_{2} \mathrm{O}_{3}$ on FoxP3 expression and cytokine secretion of ascites-derived TILs in vitro. The ELISA results showed that $\mathrm{As}_{2} \mathrm{O}_{3}$ treatment significantly reduced FoxP3 mRNA expression, with a greater effect by 5 and $10 \mu \mathrm{M}$ (P<0.01) (A). The level of IL-10 decreased significantly by treatment with $\mathrm{As}_{2} \mathrm{O}_{3}$, with a greater effect by $5 \mu \mathrm{M}(\mathrm{P}<0.05)(\mathrm{B})$, and the level of TGF- $\beta$ harvested from the supernatant of ascites-derived TILs dereased significantly, with a greater effect by 5 and $10 \mu \mathrm{M}(\mathrm{P}<0.01)(\mathrm{C})$. Proliferation of TILs treated with vehicle or As $\mathrm{O}_{3}$ was evaluated by CCK-8 assay. $\mathrm{As}_{2} \mathrm{O}_{3}$ treatment did not induce significant apoptosis of TILs ( $\left.\mathrm{P}>0.05\right)(\mathrm{D})$. ( ${ }^{\#} \mathrm{P}<0.05$, ${ }^{\# \#} \mathrm{P}<0.01$ compared with the control group; ${ }^{*} \mathrm{P}<0.05$, ${ }^{* *} \mathrm{P}<0.01$ compared between the experimental groups).

increased in $\mathrm{As}_{2} \mathrm{O}_{3}$ treatment groups, with the greater effect using a dose of $5 \mu \mathrm{M} \mathrm{As}_{2} \mathrm{O}_{3}(\mathrm{P}<0.01)$ (Fig. 4C). Furthermore, ELISA detection revealed that IFN- $\gamma$ levels in the TIL supernatants of the $\mathrm{As}_{2} \mathrm{O}_{3}$ treatment groups increased when compared with those in the control group $(\mathrm{P}<0.01)$ (Fig. 4D). In our next experiment, cytotoxicity of TILs toward BGC823 cells was assessed in an in vitro killing experiment by the LDH release assay at 5:1 and 10:1 effector-target ratios. It was found that the cytotoxic activity of ascites-derived TILs significantly enhanced $\mathrm{As}_{2} \mathrm{O}_{3}$ treatment $(\mathrm{P}<0.01)$ (Fig. 4E).

\section{Discussion}

Although immunotherapy has achieved a certain effectiveness in treating diverse malignant tumors (16-18), it frequently has to contend with immune-escape mechanisms induced by the tumors.

In the present study, we compared and analyzed T-cell subsets in ascites-derived TILs of patients, PBMCs of patients with gastric cancer, and PBMCs of healthy donors. In agreement with previous studies, we showed that ascites-derived TILs displayed an increased proportion of Tregs. Moreover, we observed that the $\mathrm{CD}^{+} \mathrm{T}$ cell/Treg ratio decreased in TILs and PBMCs of patients compared with the PBMCs of healthy donors. Indeed, the increased proportion of Tregs and a low $\mathrm{CD}^{+} \mathrm{T}$ cell/Treg ratio reflect an immunosuppressive microenvironment and may be a factor that contributes to immune escape in patients with malignant ascites. Indeed, the microenvironment in malignant tumors is suppressive for immune responses, and successful cancer immunotherapy can only be effective when associated with the elimination of suppressive cells. Because of their highly suppressive functions, Tregs have been seen as a major obstacle to successful immunotherapy. In addition, previous studies also suggest that a high concentration of Tregs in a tumor site is associated with poor prognosis $(19,20)$. It can impede antitumor cytotoxic activity in adoptive immunotherapy because of Tregs recruitment and accumulation in the tumor site and in malignant ascites (21-23). Therefore, it is of great clinical significance to explore therapeutic interventions that eliminate immunosuppressive factors.

We also observed that $\mathrm{As}_{2} \mathrm{O}_{3}$ induces selective depletion of Tregs in ascites-derived TILs in vitro. This is consistent with previous reports. Thomas-Schoemann et al (11) suggested that $\mathrm{As}_{2} \mathrm{O}_{3}$ treatment can inhibit solid tumor growth by reducing the number of Tregs, thereby leading to better survival outcomes. The exact mechanisms underlying signaling pathway of $\mathrm{As}_{2} \mathrm{O}_{3}$ function on Tregs have not been fully elucidated. It has shown that NO signaling pathway play a role in Treg depletion by $\mathrm{As}_{2} \mathrm{O}_{3}(11)$. It is related to superoxide and nitrite oxide production resulting in $\mathrm{ONOO}^{-}$accumulation. $\mathrm{As}_{2} \mathrm{O}_{3}$ is able to induce the intracellular accumulation of superoxide anions and interfere with the mitochondrial respiratory chain and membrane nicotinamide adenine dinucleotide phosphate oxidase activation $(24,25)$. Importantly, we also showed that the transcription factor FoxP3 expression in TILs was inhibited by $\mathrm{As}_{2} \mathrm{O}_{3}$ treatment. It has been proven that FoxP3 is substantially and stably expressed in $\mathrm{CD} 4^{+} \mathrm{CD} 25^{+}$Tregs. FoxP3 is a crucial regulatory gene for the development and function of Tregs because the retroviral gene transfer of Foxp 3 converts naïve 
A

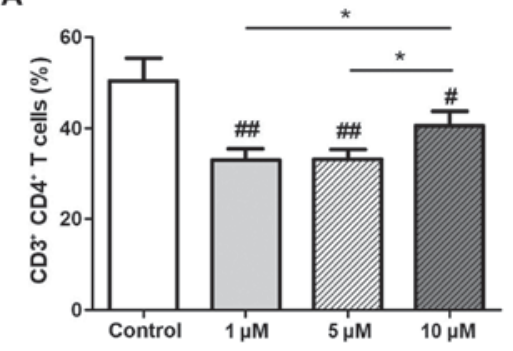

C

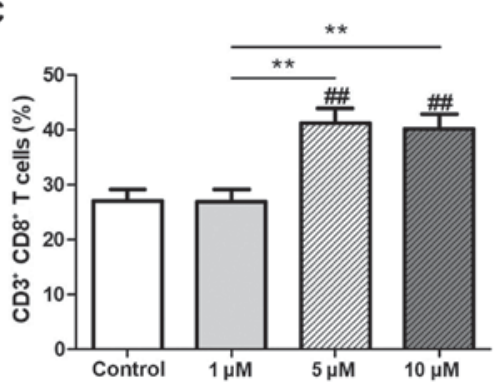

B

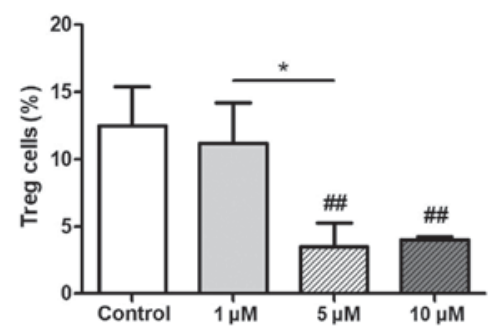

D

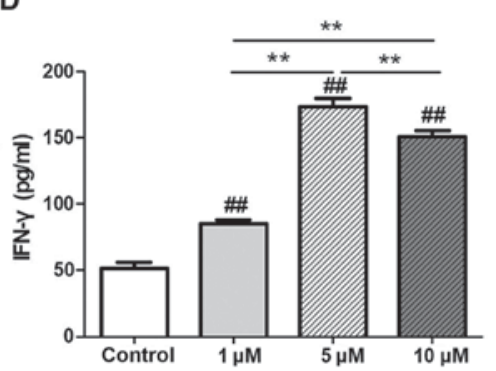

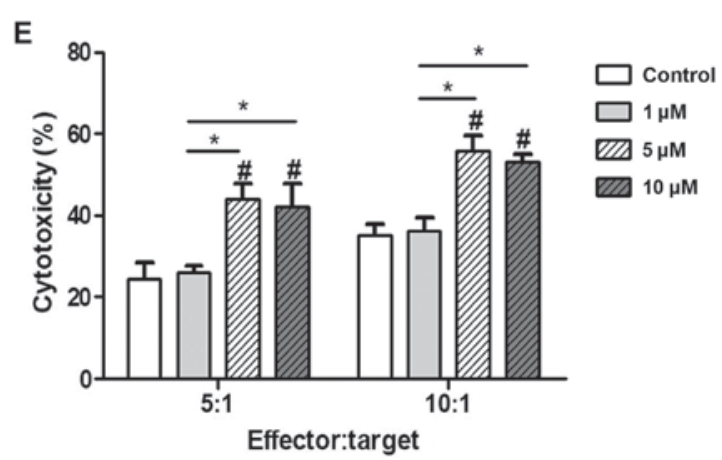

Figure 4. $\mathrm{As}_{2} \mathrm{O}_{3}$ treatment reduced the proportion of Tregs and improved the cytotoxic activity of ascites-derived TILs. The results showed that $\mathrm{As}_{2} \mathrm{O}_{3}$ treatment significantly decreased the percentage of $\mathrm{CD}^{+} \mathrm{T}$ cells, with a greater effect by 1 and $5 \mu \mathrm{M}(\mathrm{P}<0.01)(\mathrm{A}) . \mathrm{As}_{2} \mathrm{O}_{3}$ treatment significantly decreased the ratio of Tregs, with a greater effect by 5 and $10 \mu \mathrm{M} \mathrm{As}_{2} \mathrm{O}_{3}(\mathrm{P}<0.01)(\mathrm{B})$. The cytotoxic activity of ascites-derived TILs after $\mathrm{As}_{2} \mathrm{O}_{3}$ treatment was evaluated through different ways in vitro. The percentage of $\mathrm{CD}^{+} \mathrm{T}$ cells increased significantly by treatment with 5 and $10 \mu \mathrm{M} \mathrm{As}_{2} \mathrm{O}_{3}(\mathrm{P}<0.01)(\mathrm{C})$, and the level of IFN- $\gamma$ harvested from the supernatant of ascites-derived TILs increased significantly, with a greater effect by $5 \mu \mathrm{M} \mathrm{As}_{2} \mathrm{O}_{3}(\mathrm{P}<0.01)(\mathrm{D})$. As $\mathrm{O}_{3}$ treatment significantly improved the cytotoxic activity of ascites-derived TILs at 5:1 or 10:1 effector-target ratio $(\mathrm{P}<0.01, \mathrm{E}) .\left({ }^{\#} \mathrm{P}<0.05,{ }^{\# *} \mathrm{P}<0.01\right.$ compared with the control group; ${ }^{*} \mathrm{P}<0.05,{ }^{* *} \mathrm{P}<0.01$ compared between the experimental groups). The in vitro experiments were repeated three times).

$\mathrm{T}$ cells into a regulatory T-cell phenotype similar to that of naturally occurring $\mathrm{CD} 4^{+}$Tregs (26). In addition, we assessed the effect of $\mathrm{As}_{2} \mathrm{O}_{3}$ on cytokine secretion and found that $\mathrm{As}_{2} \mathrm{O}_{3}$ treatment reduced IL-10 and TGF- $\beta$ levels in TILs, corresponding with Treg levels. IL-10 and TGF- $\beta$ are indeed significant contributors to Treg-mediator suppression. It has been demonstrated that stimulation of effector $\mathrm{T}$ cells by $\mathrm{CD}_{103^{+}}$dendritic cells in the presence of TGF- $\beta$ and retinoic acid induces the generation of FoxP3 $3^{+} \mathrm{T}$ cells (27). TGF- $\beta$ has an important role in maintaining FoxP3 expression in natural Treg cells. IL-10 can maintain the regulatory activity of Tregs and impair dendritic cell function. Moreover, the tumor microenvironment promotes the generation of Tregs that mediate IL-10-dependent suppression. Indeed, IL-10 production by Treg cells appears to be important for blocking antitumor immunity. These results in our study collectively indicate that $\mathrm{As}_{2} \mathrm{O}_{3}$ treatment inhibits the function of Tregs through depletion of Tregs and weakens their functions, such as cytokine secretion.
The cytotoxic activity of ascites-derived TILs toward cell line BGC803 was examined by an LDH assay in vitro experiment. We found that $\mathrm{As}_{2} \mathrm{O}_{3}$ increased the cytotoxic activity of ascites-derived TILs at both the 5:1 and 10:1 effector-target ratios. The proportion of $\mathrm{CD} 8^{+} \mathrm{T}$ cells and effector cytokine IFN- $\gamma$ levels were also assessed. $\mathrm{As}_{2} \mathrm{O}_{3}$ reduced the proportion of Tregs in ascites-derived TILs as described above, thereby increasing the $\mathrm{CD}^{+} \mathrm{T}$ cell ratio, with a greater effect by higher doses of $\mathrm{As}_{2} \mathrm{O}_{3}$. With regard to effector cytokine IFN- $\gamma$ levels, those in $\mathrm{As}_{2} \mathrm{O}_{3}$ treatment groups were significantly higher than those in the control group. These results indicate that $\mathrm{As}_{2} \mathrm{O}_{3}$ can enhance the immune response against gastric cancer cells. Therefore, an appropriate dose of $\mathrm{As}_{2} \mathrm{O}_{3}$ may be applied as an immune adjuvant to provide an improved therapeutic effect against gastric cancer in patients with malignant ascites. Nevertheless, the exact mechanisms underlying the efficacy of $\mathrm{As}_{2} \mathrm{O}_{3}$ have not been fully elucidated; further research is needed to explore the detailed mechanisms. 
In conclusion, the present study revealed a high proportion of Tregs and low $\mathrm{CD} 8^{+} \mathrm{T}$ cell/Treg ratio in ascites-derived TILs. We showed that appropriate doses of $\mathrm{As}_{2} \mathrm{O}_{3}$ can induce selective depletion of Tregs and increase the cytotoxic activity of ascites-derived TILs by suppressing Tregs. These results offer a new strategy for use of $\mathrm{As}_{2} \mathrm{O}_{3}$ to enhance the antitumor activity of an ACT strategy.

\section{References}

1. Sakaguchi S, Sakaguchi N, Asano M, Itoh M and Toda M: Immunologic self-tolerance maintained by activated $\mathrm{T}$ cells expressing IL-2 receptor alpha-chains (CD25). Breakdown of a single mechanism of self-tolerance causes various autoimmune diseases. J Immunol 155: 1151-1164, 1995.

2. Sayour EJ, McLendon P, McLendon R, De Leon G, Reynolds R, Kresak J, Sampson JH and Mitchell DA: Increased proportion of FoxP $3^{+}$regulatory $\mathrm{T}$ cells in tumor infiltrating lymphocytes is associated with tumor recurrence and reduced survival in patients with glioblastoma. Cancer Immunol Immunother 64: 419-427, 2015.

3. Nishikawa H: Regulatory $\mathrm{T}$ cells in cancer immunotherapy. Rinsho Ketsueki 55: 2183-2189, 2014 (In Japanese).

4. Zou W: Regulatory T cells, tumour immunity and immunotherapy. Nat Rev Immunol 6: 295-307, 2006.

5. Sato E, Olson SH, Ahn J, Bundy B, Nishikawa H, Qian F, Jungbluth AA, Frosina D, Gnjatic S, Ambrosone C, et al: Intraepithelial $\mathrm{CD} 8^{+}$tumor-infiltrating lymphocytes and a high $\mathrm{CD}^{+} /$regulatory $\mathrm{T}$ cell ratio are associated with favorable prognosis in ovarian cancer. Proc Natl Acad Sci USA 102: 18538-18543, 2005.

6. Curiel TJ, Coukos G, Zou L, Alvarez X, Cheng P, Mottram P, Evdemon-Hogan M, Conejo-Garcia JR, Zhang L, Burow M, et al: Specific recruitment of regulatory $\mathrm{T}$ cells in ovarian carcinoma fosters immune privilege and predicts reduced survival. Nat Med 10: 942-949, 2004

7. Wang X, Jiang F, Mu J, Ye X, Si L, Ning S, Li Z and Li Y: Arsenic trioxide attenuates the invasion potential of human liver cancer cells through the demethylation-activated microRNA-491. Toxicol Lett 227: 75-83, 2014.

8. Powell BL: Arsenic trioxide in acute promyelocytic leukemia: Potion not poison. Expert Rev Anticancer Ther 11: 1317-1319, 2011.

9. Zhou J: Arsenic trioxide: An ancient drug revived. Chin Med J (Engl) 125: 3556-3560, 2012.

10. Li K, Zhang L, Xiang X, Gong S, Ma L, Xu L, Wang G, Liu Y, Ji X, Liu S, et al: Arsenic trioxide alleviates airway hyperresponsiveness and promotes apoptosis of $\mathrm{CD} 4^{+} \mathrm{T}$ lymphocytes: Evidence for involvement of the ER stress-CHOP pathway. Ir J Med Sci 182: 573-583, 2013.

11. Thomas-Schoemann A, Batteux F, Mongaret C, Nicco C, Chéreau C, Annereau M, Dauphin A, Goldwasser F, Weill B, Lemare F and Alexandre J: Arsenic trioxide exerts antitumor activity through regulatory $\mathrm{T}$ cell depletion mediated by oxidative stress in a murine model of colon cancer. J Immunol 189: 5171-5177, 2012.

12. Harlin H, Kuna TV, Peterson AC, Meng Y and Gajewski TF: Tumor progression despite massive influx of activated CD $8\left(^{+}\right.$ $\mathrm{T}$ cells in a patient with malignant melanoma ascites. Cancer Immunol Immunother 55: 1185-1197, 2006.
13. Xiaohui DU, Wang X, Ning N, Xia S, Liu J, Liang W, Sun H and $\mathrm{Xu}$ Y: Dynamic tracing of immune cells in an orthotopic gastric carcinoma mouse model using near-infrared fluorescence live imaging. Exp Ther Med 4: 221-225, 2012.

14. Wing JB and Sakaguchi S: Multiple treg suppressive modules and their adaptability. Front Immunol 3: 178, 2012.

15. Collison LW, Pillai MR, Chaturvedi V and Vignali DA: Regulatory $\mathrm{T}$ cell suppression is potentiated by target $\mathrm{T}$ cells in a cell contact, IL-35- and IL-10-dependent manner. J Immunol 182: 6121-6128, 2009.

16. Makkouk A and Weiner G: Cancer immunotherapy and breaking immune tolerance: New approaches to an old challenge. Cancer Res 75: 5-10, 2015.

17. Chia WK, Teo M, Wang WW, Lee B, Ang SF, Tai WM, Chee CL, Ng J, Kan R, Lim WT, et al: Adoptive T-cell transfer and chemotherapy in the first-line treatment of metastatic and/or locally recurrent nasopharyngeal carcinoma. Mol Ther 22: 132-139, 2014.

18. Jin CG, Chen XQ, Li J, Wu ZP, Liu X and Wang XC: Moderating effects and maintenance of lung cancer cellular immune functions by CIK cell therapy. Asian Pac J Cancer Prev 14: 3587-3592, 2013.

19. Vlad C, Kubelac P, Fetica B, Vlad D, Irimie A and Achimas-Cadariu P: The prognostic value of $\mathrm{FOXP}^{+} \mathrm{T}$ regulatory cells in colorectal cancer. J BUON 20: 114-119, 2015.

20. Lee WS, Park S, Lee WY, Yun SH and Chun HK: Clinical impact of tumor-infiltrating lymphocytes for survival in stage II colon cancer. Cancer 116: 5188-5199, 2010.

21. Lechner A, Schlößer H, Rothschild SI, Thelen M, Reuter S, Zentis P, Shimabukuro-Vornhagen A, Theurich S, Wennhold K, Garcia-Marquez M, et al: Characterization of tumor-associated T-lymphocyte subsets and immune checkpoint molecules in head and neck squamous cell carcinoma. Oncotarget 8: 44418-44433, 2017.

22. Zhou Q, Bucher C, Munger ME, Highfill SL, Tolar J, Munn DH, Levine BL, Riddle M, June CH, Vallera DA, et al: Depletion of endogenous tumor-associated regulatory $\mathrm{T}$ cells improves the efficacy of adoptive cytotoxic T-cell immunotherapy in murine acute myeloid leukemia. Blood 114: 3793-3802, 2009.

23. Nishikawa $H$ and Sakaguchi S: Regulatory $T$ cells in tumor immunity. Int J Cancer 127: 759-767, 2010.

24. Lemarie A, Bourdonnay E, Morzadec C, Fardel O and Vernhet L: Inorganic arsenic activates reduced NADPH oxidase in human primary macrophages through a Rho kinase/p38 kinase pathway. J Immunol 180: 6010-6017, 2008.

25. Chou WC, Jie C, Kenedy AA, Jones RJ, Trush MA and Dang CV: Role of NADPH oxidase in arsenic-induced reactive oxygen species formation and cytotoxicity in myeloid leukemia cells. Proc Natl Acad Sci USA 101: 4578-4583, 2004.

26. Hori S, Nomura T and Sakaguchi S: Control of regulatory T cell development by the transcription factor Foxp3. Science 299: 1057-1061, 2003.

27. Vignali DA, Collison LW and Workman CJ: How regulatory T cells work. Nat Rev Immunol 8: 523-532, 2008.

This work is licensed under a Creative Commons Attribution-NonCommercial-NoDerivatives 4.0 International (CC BY-NC-ND 4.0) License. 